\title{
CHANGES IN CULTURAL ETHICS IN RANDAI IN MINANGKABAU
}

\author{
Zulkifli, Erlinda \\ Institute of Indonesian Arts, Padang Panjang
}

\begin{abstract}
Randai as a folk theater tradition of Minangkabau has not only grown and developed in the traditional community environment but has also expanded to the urban community environment, schools and colleges. Efforts to find the theoretical definition of Randai and its technical development are increasingly widespread, both by artists in and outside Minangkabau. This creativity becomes a necessity if we want Randai to survive, living and growing together with the always changing and developing lives of the people. Studies and research on changes in cultural ethics in Randai also focus on women's Randai "Sirabuang Ameh," which is technically different from men's Randai that had existed before.

Changes and developments in Randai's texts and context, directly or not, affect the cultural ethics in the art of Randai itself. This research used a product-based method. Randai development uses the concept of art as a valuable experience originating from creative imagination. The purpose of this article was to discuss the changes in cultural ethics as a result of the change and development of Randai as the traditional theatre of the Minangkabau people.
\end{abstract}

Keywords: women's Randai, cultural ethics, and forms of performance.

DOI: $10.7176 / \mathrm{ADS} / 76-09$

Publication date:September $30^{\text {th }} 2019$

\section{INTRODUCTION}

Randai is a theater tradition of the Minangkabau people that grows, lives, and develops in the communities of villages in the Minangkabau region. It is called folk art because Randai is inherent in the traditions that apply in the life of the Minangkabau people. Randai functions in wedding ceremonies, Batagak Panghulu (Appointment of Tribal Leaders) ceremonies, traditional Minangkabau folk entertainment ceremonies, and so on. It was born out of the people, by the people and for the people of Minangkabau. As a form of art, Randai was formed out of the treasures of art and culture and serves to express the cultural values of the Minangkabau people as a supporting community.

The word Randai in Minangkabau was originally a term for the type of dance performed by several dancers in a circular formation, singing and clapping. In the dance there was no element of dialogue, character and characterization. After that came the traditional theater of the Minangkabau people with circular floor pattern which then became the Randai that we know today. Thus there are two types of Randai arts in Minangkabau: Randai dance and Randai theater. In their developments, the dance type is called Randai dance and the theater type is called just Randai (Zulkifli. 2016: 2).

Minangkabau is an ethnic group that has specificity and uniqueness in ideology and manners of life. The familial system is known as the matrilineal system, in which descendants are identified according to the maternal lineage only, and so is how heritage and inheritance are passed down. This means that children belong to their mother's family or clan, instead of their father's (Bronislaw Malinoski, 1955: 22). A women's children and her sisters are said to be siblings or sepersukuan (having a kinship). The father does not belong to the sepersukuan of the mother and children. He is called Sumando, which means someone who has been brought in from another tribal family to give offspring. Women are determinants of lineage; while their brothers, who are commonly called Mamak, are defenders and advisors of the sepersukuan descendants (Erianjoni, 2011).

The Minangkabau people are very concerned about the comfort of women's lives. They must be protected and defended materially and morally. If this is not the case, the morals or ethics of their offspring will be corrupted and bad. Materially the Minangkabau women have the right and obligation to save and regulate the use of tribal family assets. They are regarded as Ambun Puro, which means key grips or treasurers. Agricultural products from the fields and houses are for them. Morally, the mothers in Minangkabau are also protected. Mamak or their brothers are obliged to maintain the morale of women in their sepersukuan. Women of bad morals are said to have descendants and tribal families of bad moral as well in the future (Erlinda, 1999: 1). This would be an insult in the community life of Minangkabau people.

Humanitarian values for the Minangkabau community depend on morals or ethics. If a person's morals or ethics are damaged, then that person's human value is destroyed. They will not be valuable and excluded in social life. Raso or pareso, (thoughts or logic, feelings or morals), modesty and courtesy are the main elements of the Minangkabau custom. Minangkabau people must use the four main elements of these customs values. If one basic element is absent in one's life, he/she is said to have no ethics or character. Directly or not, he will be marginalized in social life. 
Good character or good ethics based on the norms of Minangkabau customs in this context are understood as the Minangkabau cultural ethics. Cultural ethics are the embodiment of thoughts and feelings, and will develop and change in line with the development and change of the people's thoughts and feelings. This article intentionally explains the development of cultural ethics in Randai in Minangkabau. with the following focus of the problems; What is the form of development and changes in cultural ethics in Randai? Why are developments and changes happening? What is the impact on Randai's life and development as the traditional theater of the Minangkabau people? It is expected that this study and presentation can increase understanding of Randai theater in Minangkabau.

\section{METHOD}

Randai is a traditional theater of Minangkabau. As a traditional theater, Randai is attached to the traditions that prevail in its society. Randai appears and plays a role in traditional events and also expresses and reflects the cultural ethics of the Minangkabau people as its supporting community.

The study of Randai in the socio-cultural context will refer to two aspects:. First, the presence and development aspect of Randai as a work of art; and second, the aspect of changes in social culture behavior of the supporting community. The discussion of these two aspects requires a multi-layered approach. In this regard, Soedarsono (2003: 8-10) states that the multilayer approach applies theories from various disciplines, including history, anthropology, aesthetics, religion, politics and language or hermeneutics. The multi-layered approach is very helpful in discussing Randai as a cultural expression and reflection of beauty. In this way the various dimensions of life that lay behind the growth and development of Randai will be clearly revealed.

The concept of Randai creation as a work of art is related to what is stated by Alma M. Hawkins (2003): The creation of a work of art starts from experiencing, expressing, seeing, feeling, imagining, manifesting, and forming. The process is adopted in the cultivation of works of art, including Randai.

Randai as a socio-cultural product will change and develop in line with changes in the culture of the supporting community. Culture is not an inanimate object, but it lives and is lived by its people. Cultural changes are closely related to the products of arts. This concept occurs in the technical and aesthetic development of Randai, so that changes in Randai cultural ethics are inevitable. The study of changes and the development of Randai cultural ethics are guided by the opinion of Mursal Esten (1992) which states that an art form must develop in accordance with the development of life. If not, the art will be abandoned by the life of the people which is always developing and changing. The development of Randai is the responsibility of the artist, so due for his survival, it requires creativity, brilliant ideas, and hard work from supporters (Suryanti, 2014: 151)

\section{SHAPE OF CHANGE OF RANDAI CULTURAL ETHICS}

In the 1920s Malacca Malay artists performed the Komedi Bangsawan Melayu or Malay Nobility Comedy show in places where Malays lived. The performance was well received by the people of Indonesia. In fact, it inspired the emergence of several types of traditional theater in the Indonesian Archipelago, such as Ketoprak in Java, Lenong in Betawi, Mak Yong in Riau, Randai in West Sumatra, Abdul Muluk in Jambi, and Mamanda in Kalimantan (Sahrul, 2012: 221).

Not unlike other regions of the archipelago, in West Sumatra the Malay aristocratic theater received good reception. This was proven by the establishment of two theater buildings that host Teater Bangsawan shows in the City of Padang in the 1920s: the Comedy building on Jalan Thamrin near what is Grend Hotel today and the Comedy building in the Pondok area (Rusli Amran. 1986: 21). The two buildings give enough proof that at that time the people of West Sumatra in general and the people of Padang in particular enjoyed watching the performance of Komedi Bangsawan Melayu.

The pleasure of the people of West Sumatra was also demonstrated by the development of the Komedi Bangsawan to schools, such as the INS (Indonesia Nederland School) in Kayu Tanam and Kweekschool (School of the Kings) in Bukittinggi. The pleasure continued with their efforts to work on and present the Bangawan Melayu theater featuring classic Minangkabau stories such as the story of Cindua Mato, Anggun Nan Tongga and others.

Since Indonesia was under the Dutch colonial rule, the term theater was not longer popularized, replaced by the Dutch as Tonel. Tonel that features the classic Minangkabau story is called the Minangkabau Classic Tonel. In 1932 when there was a Funcy Faer or Night Market in Payakumbuh, the Minangkabau Classic Tonel was performed, entitled Talipuak Layua Nan Dandan by Datuak Panduko Basa. Inspired by the Layal Nan Dandan Classic Ralipuak Tonel, three Paya Kumbuh artists, namely Jalut, Ilyas Datuak Ratih and Datuak Panduko Basa, created a new form of theater which was finally called Randai.

The first piece of Randai presented the story of Cindua Mato, and the second was Anggun Nan Tonggo. Previously, the two stories were commonly presented by the people of Minangkabau, West Sumatra in the form of "kaba", known as Bakaba, which is a kind of speech art. In 1935 a new Randai emerged, taking place at 
Labuah Basilang Payakumbuh which featured the Simarantang story that told the real life of Simarantang and Munah Kayo. This shows that the Randai stories by the Minangkabau Society of Sumatra are not always based on classic stories that are legends or myths, but can also be new stories originating from real life events (Zulkifli.1999: 65-69).

Randai's development or manifestation initially took place in sasaran, which was an open ground floor where Minangkabau men learned the Silat martial arts and night dance. Because of this, Randai was originally only performed by men, with a Minangkabau-shaped pattern of motion or silhouette. When the Randai show needed a woman role, a man would dress and act like women to play the role.

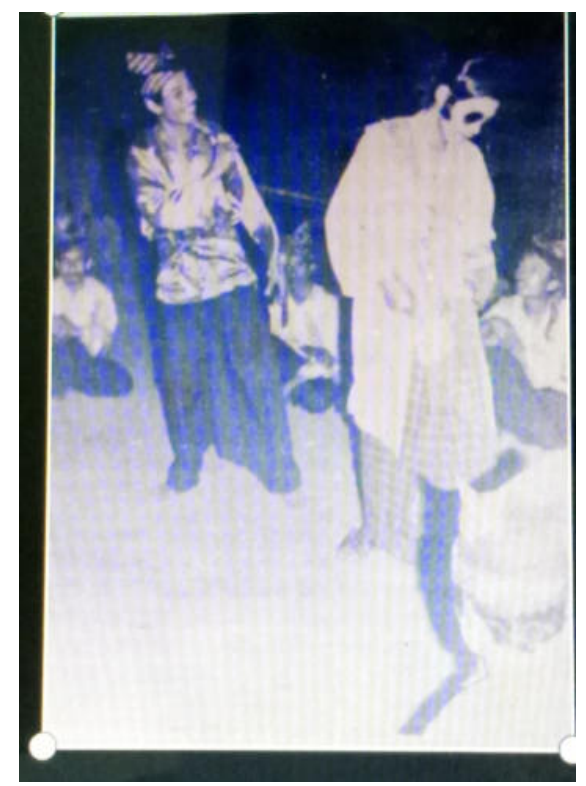

Figure 1

One of the dramatic scenes of Simalanca Randai by the Randai Ikan Sakti group of Sungai Janiah Village, Agam Regency. A man is seen as a woman wearing kebaya clothing and sunglasses (Photo reproduction of Chairul Harun 1992).

According to Minangkabau cultural ethics, women in their teenage years were no longer allowed to leave the house. They had to confine themselves and became what was commonly called gadis pingitan or 'a girl who is kept in the house.' When they wanted to go out, they should be accompanied by a male family member to avoid being harassed by other men. That way, the Minangkabau women's morals would be protected. According to Minangkabau customs, a good woman was morally and ethically responsible, a good cook, kept her clothes and house clean, was good at sewing, cared for the children, and was courteous and respectful toward her husband. All of these kindnesses and devotions were enough to be done at home. Minangkabau women were not required to work outside, let alone to work as an artist that required them to perform in public as according to the ethical culture of Minangkabau the profession was only to be performed by men. This cultural ethic was one of the reasons why Minangkabau women could not play a role in Randai in the past.

Minangkabau's cultural ethic regarding women's participation in Randai as described above did not last. The paradigm changed as the Minangkabau people increasingly embraced the teachings of Islam as the basis of their customs. The teachings of Islam emphasize that men are forbidden from dressing and acting like women, and vice versa. The practice of Islamic teachings has influenced Randai's development in Minangkabau. The phenomenon was reflected in the emergence of female performers to play the female roles in Chairai Harun's 
Randai Ikan Sakti in the village of Sungai Janiah, Agam Regency, West Sumatra. Although the treatment was correct according to Islamic teachings, Harun as an artist and cultural person of Minangkabau was wise enough not to feature a female performer from Sungai Janiah where he created Randai. Instead he hired a Minangkabau woman from another area, Mustika Sharif from Padangpanjang, West Sumatra. If Chairul Harun had decided to feature a woman from Sungai Janiah, it would have been highly unlikely that she would take the offer because it was not the culture of the area, unlike Mustika Sharif who was brought from Padangpanjang. Although she lived in the traditional culture of Minangkabau, her custom was quite different - Minangkabau customary norms, in this regard the Salingka customs, only applied to other villages. Thus the customary norms in Sugai Janiah did not apply to Mustika Sharif who was a Padangpanjang woman. Furthermore, Mustika Sharif did not appear in the customary culture of her region. The people of Singai Janiah did not see her as one of their children or family members.

Chairul Harun's decision to let female performers play the role of women in Randai Ikan Sakti in Nagari Sungai Janiah actually did not get challenged and ran smoothly. Although secretly there were pros and cons in the Minangkabau society about it, Harun's idea slowly continued to develop and was followed by other Randai groups. Around the 1980s there were no more men in women's costume playing female characters in Randai in Minangkabau.

It was all quite different from what Zulkifli, a lecturer in the Indonesian Art Institute of Padangpanjang, did. When teaching Randai lectures, he did not differentiate Randai teaching materials for men and women. All students received the same learning material. Girls took part in learning and doing galombang, which is circular motion accompanied by hand-claps and silat-style moves, while wearing pants, destar and sisamping which were commonly worn by Minangkabau men. When presented as part of a field practice lecture off campus, the Randai surprisingly received a positive response from the community. Many people admired the Randai show that Randai Palimo Gaga, which was created and taught by Zulkifli, was often asked by the public to perform in and outside the area of West Sumatra. Even some Randai practitioners in West Sumatra, especially the Randai group in urban and school environments, also included women as galombang performers.

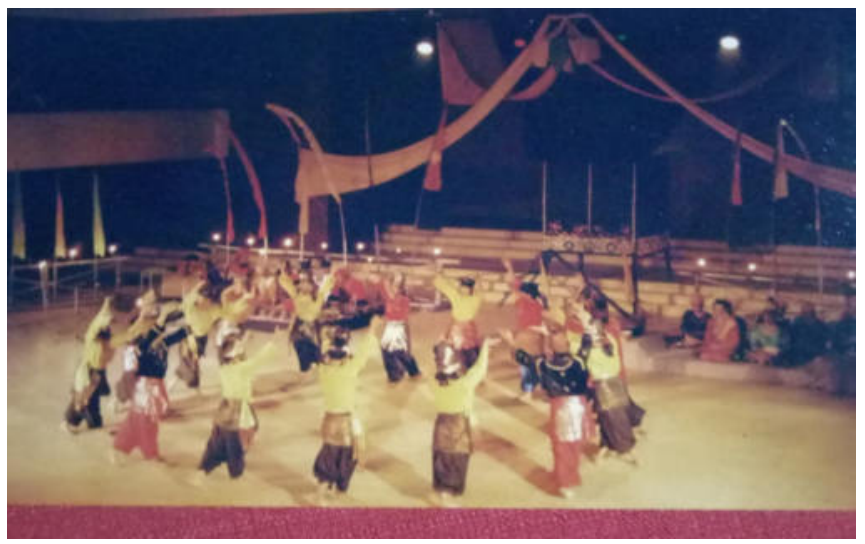

Figure 2

Randai Palimo Gaga's performance at Purna Budaya Yogyakarta. Managers of setting, decoration, and lighting can be seen at the show. (Zulkifli Collection, 1993).

When taking part in the traditional Randai festival in West Sumatra at the Cultural Park in Padang City in 1987, Randai Palimo Gaga emerged as the first winner. It seemed that the Randai judges or observers at the 
time did not question the women who played galombang in men's costume and moved like men. Upon hearing the news about Randai Palimo Gaga's victory in the traditional Randai festival throughout West Sumatra, Boestanoel Arifin Adam - an artist and cultural figure who was also a former Director of the Indonesian Karawitan Art Academy (ASKI) of Padangpanjang - said that the community had accepted the developments made in the Randai show.

The participation of women in Galombang Randai seemed to be accepted only by a part of the Minangkabau community in West Sumatra; others were quiet at that time. Further studies and understanding of randai as a Minangkabau folk theater that must reflect Minangkabau cultural ethics generated new insights. West Sumatra Minangkabau culture and artists did not justify Minang women taking part in galombang Randai, moving and dressing up like men, because it was considered damaging to the image of Minangkabau women. Zulkifli as the originator of that matter seemed to understand; it was not that women were not allowed to perform in Randai shows, but the form or character of such art was not appropriate for women, especially in terms of costumes and movement.

Zulkifli as an activist and practitioner of Randai was good at seeing opportunities in the matter. He created and worked on a new Randai that were relevant to the characteristics of Minangkabau women. His decision showed that the ethics of Minangkabau culture did not forbid women from participating in Randai shows, but they just encouraged the women not to violate the attitudes and characteristics of Minangkabau women when performing.

The creation of women Randai "Sirabuang Rabuang Ameh" by Zulkifli in 2018 offered of a new form of Randai that was different from the existing men Randai. The difference lay in Zulkifli's efforts in working on or creating all the Randai elements and the nature of presentation that reflected the cultural ethics of Minangkabau women.

"Sirabuang Ameh" was originally a legend that told of a poor woman with her two children. One night the children were hungry and asked for food from Sirabuang Ameh. Because there was no food that could be served, Siabuang Ameh tried to go outside to look for some. She got rabuang, young bamboo that had just grown and could be boiled and made a dish. But when she boiled the rabuang, it turned into gold. That was the beginning of the legend called Sirabuang Ameh. The legend of Sirabuang Ameh is considered suitable to be used as a story for women Randai because it can be developed to tell the lives of women according to Minangkabau cultural ethics.

The development of the story is done by revealing household conflicts experienced by Sirabuang Ameh after her husband decided to remarry. She refused to live that kind of life even though her customs and religion forced her to get used to it. The attitude of Sirabuang Ameh is against the principles of her tribal and mamak families because the life of a widow is a disgrace and an affront to the family, especially against mamak or her ethnic brothers. Mamak was angry at Sirabuang Ameh's attitude and did not allow Sirabuang Ameh to take the agriculture products from their fields even though according to customs those are for her and her only source of livelihood as a Minangkabau woman. Because it was no longer possible to live in the village, Sirabuang Ameh left home and lived wandering aimlessly. Sirabuang Ameh's behavior presents a change in Minangkabau cultural ethics in Randai art because traveling away from home is something that only Minangkabau men do, not women. Minangkabau Randai stories are generally kaba stories, which follow the life journey of the main character. They usualy tell about the joys and sorrows of a man leaving his home. Along the way he would be attacked or robbed, resulting in a fight. In the fight, the actor would demonstrate the Minangkabau Silat skill. The fighting that demonstrates the expertise of the Minangkabau Silat is an element of Randai art that is rarely left behind in a Minangkabau Randai show even though it is not an essential element.

Changes and developments in Randai gave rise to new Randai stories that did not feature a robbery, so there was no element of fight in the story. It seems that the change occurred due to two factors. First, the culture of robbery did not need to be preserved anymore in Randai Minangkabau. Second, the actor could not perform the Minangkabau Silat well; if forced, he would completely taint the overall show.

Typically, the Randai show procession began with all performers entering the stage, accompanied by musical instruments talempong pacik or talempoang jinjiang. Galombang performers or dancers entered the arena by demonstrating movements similar to those of Silat in two rows of lines. Once everyone entered the arena, they got down on their knees, raised their hands above their heads, and bowed down to the audience as a sign of asking permission to start the show. This gesture has, however, changed among some Randai groups today. They no longer bow down on their knees, instead they move in a standing position to the rhythm of singing or Dayang Daini song that is usually played as the opening sign of a Randai show.

The story of Sirabuang Ameh Randai is generally supported by female performers. Of the eight performers, only two are male - they act as mamak and husband. These two male performers are not included in the group of galombang performers or dancers because all galombang performers or dancers are women, in contrast to the general Randai stories which are dominated by men, including the galombang performers. This condition also caused a change in bow-down gesture in the opening of a Randai show. All female performers of Sirabuang Ameh Randai would enter the stage, not with silat movements, but just by walking in two rows of 
lines while hitting the drum accompanying talempoang pacik or talempoang jenjeang music. They do not bow down on their knees, but they do it while standing up, moving to the rhythm of Dayang Daini song. This change occurs because women are not allowed to behave like men. If they do it like the men, it would violate the ethics of Minangkabau women.

Galombang or a motion in a circular position is one of the main elements of Randai that must not be eliminated. Usually the galombang movements are similar to those of Silat accompanied by hand-claps and pantclaps or galembong. Originally the galembong claps were done by bending the body forward and moving one of the feet forward or sideways, so that the sole of the foot was not raised high in front of the audience; raising the sole of your foot in front of the audience was considered rude and violated the ethics of Minangkabau culture. However, in the development of Randai, this rule did not last. Randai artists today change their movements in doing the galembong claps. They deliberately lift the soles of the feet high, with some even jumping and laying on their backs with two legs wide open. In a way, such attraction looks interesting and aesthetic. Although the Minangkabau ethics do not justify that attitude, along with the growth and development of Randai, that movement is increasingly commonplace. This phenomenon shows that the aesthetic demands of art or Randai shows would, directly or not, change the ethics of the cultural performances of art or Randai itself. This is different from the attitude of the women's Galombang Randai - the performers do not demonstrate silat movements, but a style of Minang dance instead, with agile and graceful movements, unlike the male galombang movements that have a large amount of space and high energy.

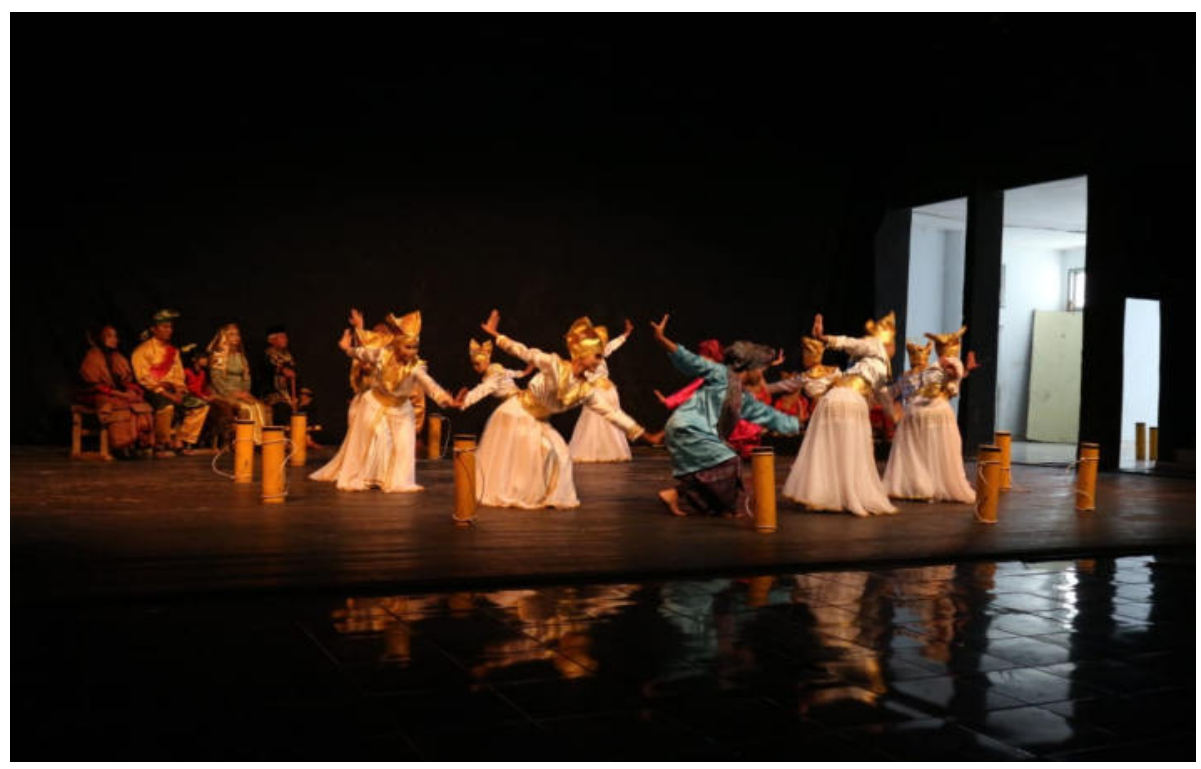

Figure 3.

Women's Randai “Sirabuang Ameh” show in Jambi Cultural Park. The female performers displayed the galombang movements. (Photo: Zulkifli collection, 2018)

In a women's Galombang Randai show, the women do not do the galembong or pant claps. In addition to the players not wearing galembong costumes, the move of raising the feet up is also absent in a women's Galombang Randai show as it does not reflect the cultural ethics of Minangkabau women.

Dialogue and Acting are the key elements in Randai and are often called barundiang or negotiate. Some Minangkabau traditionalists call Dialogue ma-adu kato (pitting words) and Acting melapeh kato or the way to release or convey the words. Traditionally, Randai's dialogue in Minangkabau's literary language is in the form of a poem or Bidato Kato with free rhymes, unlike a poem tied to the suffix a.b. a.b. or a.b.c a.b.c.. The Randai literary language tends to be expressed in the form of petatah and petitih and contains metaphors and parallels with Minangkabau cultural customs. Randai's acting style is the Silat martial arts, setting the feet apart and stretching your arms like a Minang who is in a Silat pose. The combinatiom of Randai's style, dialogue and acting looks very elegant and reflects the cultural traditions of the Minang people in negotiation. When Randai's dialogue does not use the traditional language of Minangkabau, but is modified and developed in the daily form of the Minang language, it also changes Randai's acting style into a modern theater style. Moreover, while Randai's dialogue uses Indonesian and English literature, the acting style becomes very different from the the 
balabeh Silat of Minangkabau. This phenomenon indicates that language changes will, directly or indirectly, change the style of acting. The act or style of expression is a cultural etiquette. The same is true of Randai's art as a traditional Minangkabau theater. Thus the change and development of Randai's language or dialogue demands a change in acting that is directly related to Randai's cultural ethics.

The dialogue in Sirabuang Ameh which is a women's Randai of Minangkabau continues to use Minangkabau literary language. However, since the Randai is performed by women, the acting is different from the Randai acting that men usually do. Under normal circumstances the women's Randai acting space is smaller with the head slightly lowered. While men's Randai acting demands a larger space of movement, with their heads perpendicular to the style of the balabeh Silat of Minangkabau. Female Randai performers who act like men certainly do not reflect the character of Minangkabau women. In the embodiment of women's clothing that reflects the characteristics of Minangkabau women, the ethical dialogue of their performers will naturally adjust.

Another basic element of Randai is gurindam, which is the delivery of stories in the form of songs. Originally the Randai songs were performed by men who dressed and acted like women, who were commonly referred to by the Minangkabau community as biduan. When they realized that men dressing up and acting like women and vice versa was forbidden in Islamic teachings, Minangkabau men as followers of Islam no longer wanted to play a role in a Randai in a women's costume and attitude, as such treatment was seen as inappropriate by Minangkabau traditional norms and Islamic teachings. As a result, there are no more men who dress and act like women in a Randai gurindam.

Initially the gurindam performers consisted of at least two people who appeared in the middle of the circle by singing without musical accompaniment. They sang alternately, sometimes also accompanied by galombang performers. Gurindam performances like this have become a necessity in Randai art. It is said to be a necessity because gurindam tells a series of stories or the journey of the main character. If it is not carried out continuously, the delivery of the story is not focused and if the lyrics of the poem is done repetated, then the delivery time of the story will be long and boring. This nature of gurindam presentation gives the singer a chance to be creative in giving rhythm variations to the song he/she is singing. The independence of the singer in this matter becomes apparent. They must memorize the series of events and sing the lyrics without looking at the text; in fact, a gurindam performer is sometimes able to spontaneously create a poetry. The development and change of today's Randai gurindam can be seen when the singer takes a position outside the circle, sitting with an external music players, as if they are singing to accompany the dance or galombang movements. They do not feel to be a character who has the role of telling the story. In addition to changing ethics, changes like these also affect the aesthetic of Randai. The changes in gurindam presentation in a Randai occur usually because the gurindam performer does not memorize the storyline, or is unable to cite the lyrics of the poem spontaneously, or he/she has to sing near the external music players. If teh later is the case, then the use of external music in Randai is the cause of change in the way Randai is delivered.

The women's Randai "Sirabuang Ameh" by Zulkifli also lets the gurindam performer sit with an external music players outside the circle of the galombang performers. The reason is because the galombang dance movements in women's Randai displays a variety of floor patterns and require a large space and musical properties like gendang (drum). If the gurindam singer is positioned in the middle of the circle, she will clearly interfere with the movements of the galombang performers.

The Randai costume is based on the outfit of a pesilat (male Silat fighter) - it consists of a destar (headband), Balango taluak shirt, sisampiang, and high-waisted galemboang pants. Pesilats generally wear black shirts and pants. For the destar and sisampiang, they generally use a sarong or other fabric that is suitable to be used as destar and sisampiang. There are no color restrictions for the destar and sisampiang - any color can be used. Although destar and sisampiang are not everyday costumes of Minangkabau men (worn only as complementary clothing), they always wear them when learning Silat or appearing in a performance.

When taking part in a traditional ceremony, Minangkabau men generally wear a headgear - it can be in the shape of destar or in the form of a cap. If they appear to carry out any task in traditional ceremonies, in addition to wearing headgear, they also wear sisampiang. This custom is inherent and has become the cultural ethics of Minangkabau men. It would feel awkward and unethical for them if they don't wear these clothing pieces. The norm is preserved in Randai as a Minangkabau traditional theater; therefore, it explains why Randai performers always wear destar and sisampiang.

During the period of 1930 s to 1960 s, the provision of Randai costumes became the responsibility of each performer, instead of the group. Each performer was free to wear costumes that were suitable for the role they were playing. As a result, in one Randai group, there was in a variety of costumes in terms of color, model and fabric. Regardless of whether or not it was harmonious, that condition actually reflected a sense of togetherness and freedom.

Since the 1980s, Randai's existence as a folk theater began to change. Randai was no longer a social activity in a nagari (village), but was turned into a professional activity of certain groups. This change affected the management of Randai productions. Randai began to be produced with clear management; each department 
was required to be responsible and had authority over their duties. The person in charge of organizing and preparing the costumes must be responsible for the costumes for all Randai performers. The spirit of togetherness and freedom of Randai performers became marginalized. Randai was no longer a common asset of the nagari community, but had become the property of professional groups. Other communities must pay for this professionalism if they wanted to have a Randai show. As a result, the cultural ethics of Randai changed from a social activitiy to a professional one.

In the previous description it was explained that in the beginning the roles of women in a Randai show were played by men who dressed and acted like women. The costumes they wore in these roles were the "Kebaya" clothing that consisted of Kebaya dress, the Kodek Kain Batik, and Salempang scarf. Meanwhile, the hair was made to look like a bouffant with a bun, and they wore high-heeled sandals. The "Buju Kurung," even though it is a traditional Minangkabau costume, was rarely worn. This facts indicate that the Randai costumes in the early period of its development were not based on Minangkabau traditional costumes - they were created based on the culture that underlay the development of Randai art.

The Kebaya clothing is the perception of Indonesian women towards Malay women's costumes and has also been appreciated as the National Costumes of Indonesian women. This kebaya clothing is also commonly worn by Minangkabau adult women or married women as daily costumes. But Kebaya has never been worn by Minangkabau women in formal traditional ceremonies. Minangkabau women developed the Kebaya dress by creating a longer model than the previous kebaya dress. The length of the previous kebaya dress only reached the hips, but in its development the Kebaya in Minangkabau was made to reach the knee. Thus, in Minangkabu there are two models of Kebaya, short Kebaya and long Kebaya. In the past, both of these Kebaya models were commonly worn by male performers who played female characters in a Randai show.

The above description shows that the Randai costume in Minangkabau did not use traditional clothing, but rather a costume that was modified from the everyday clothes of the Minangkabau people. This attitude indicates that the artists of Minangkabau separated the Randai costumes from the traditional clothes. To them traditional clothes were not appropriate to be worn as the costume of Randai performers because it would violate the cultural ethics of the Minangkabau people.

Around the 1980s, these views and attitudes began to change. Randai performers started to wear traditional costumes, especially those who played the roles of Pangulu (tribal leader), Bundo Kanduang, brides and grooms, etc. This change had the support of the Government Agencies of West Sumatra. They provided the costumes to the Randai groups by directly purchasing the costumes for them. Generally the given costume was traditional clothing. The Randai groups who received the costume used them for their performers. Maybe it was because that was the only costume available. However, whether they realized it or not, the change affected Randai's cultural ethics, especially in terms of the costumes they wore.

The costume design of women's Randai "Sirabuang Ameh" was updated. They no longer wore male Randai costume models that existed before. However, despite the update, this design still characterized Minangkabau women's clothing, which was Baju Kurung and Kebaya. The combination of the two Minangkabau women's clothing models became the basis and the idea of creating the costume for the women's Randai "Sirabuang Ameh."

The costume for "Sirabuang Ameh" Randai consisted of a headgear designed based on the behavior of Minangkabau women by streamlining the model to make it more practical when worn in a Randai show, especially when they performed the movements. They once tried wearing the tingkuluak tanduak model, but because it was a Bundo Kanduang clothing, the model was deemed inappropriate for ordinary women and especially in the arts. According to Minangkabau cultural ethics, Bundo Kanduang is an elder or respected person in the Minangkabau traditional institution. She is the owner of the art, not the artist.

The dress designed based on Kebaya and Baju Kurung then gave birth to clothes that could cover a woman's aurah (body parts that need covering according to Islamic teachings) but still displayed the aesthetics. The model of the Minangkabau women's Baju Kurung was too loose and long, thus obscuring the beauty and practicality of movements. Meanhile, the model of Kebaya clothing with the part of the chest open was deemed too tight and short, and not covering a woman's aurah. If worn as a women's Randai costume, the model was considered not to characterize the culture of Minangkabau women.

The lower part of the Randai costume is based on a skirt model to make it look bigger and have an aesthetic effect. In order to perfectly cover women's aurah, under their skirts they wear pants like those of Minangkabau female dancers. Apart from that, the lower part of the costume for women's Randai is also equipped with side parts like men's costume that are designed to be bigger and longer; while the front part is separated so that it can be opened and look aesthetically pleasing when they move. In addition to scarves, tops, and skirts, costumes of women's Randai are also equipped with a stoka as a chest cover. The design of the stoka is based on the Minangkabau female stoka. Stoka is expected to be a hallmark of the costume of Minangkabau women's Randai. 
All the costume models of women's Randai "Sirabuang Ameh" are new designs. It may be preserved and developed to seek perfection. Certainly costumes of women's Randai should not be the same as those of men's Randai because that would violate the Minangkabau cultural ethics. The color of the Sirabuang Ameh Randai's costume is dominated by white, although according to Zulkifli, white is not a must. Other colors can be used if they give better looks. Likewise with the costume model, they can be changed and developed.

In the beginning, the cultural ethics of inviting a Randai group were as follows: the event organizing committee should send two or three people to request the willingness of the Randai group to perform. After an agreement and decision regarding the time of show was reached, the Randai group would hand in a rectangular flag bearing the name of the group, the title of the story and the nagari that owned the Randai group. The flag was then installed at the venue as a promotional media, to indicate that a Randai performance would be held at that place. These ethics of inviting Randai is no longer practiced today. The procedure for inviting a Randai group today is done only by sending an invitation letter. The Randai group does not need to send a flag as a statement of agreement and promotional media, either. In fact, most Randai groups today don't have flags. This procedure changes the cultural ethics of inviting a Randai group as well as the sense of ownership of the group. In the past, the Randai group was deemed to belong to the nagari community, but today they are more of a private property or the property of a certain group. The change in the sense of ownership also affects the sense of responsibility towards the art group.

Changes in the text and context of Randai cause changes in Randai cultural ethics as well. Changes in cultural ethics of Randai in Minangkabau, West Sumatra can be seen in the following table:

\begin{tabular}{|c|c|c|}
\hline No & Year & Randai Cultural Ethics \\
\hline 1 & $\begin{array}{l}1932 \\
1983\end{array}$ & $\begin{array}{l}\text { - All Randai performers were male. If the roles of women were needed, then the men would } \\
\text { dress and acte like women. } \\
\text { - The costumes were prepared by each performer, not by the group, so the colors, fabrics and } \\
\text { models varied. } \\
\text { - A Randai group had a flag of unity belonging to the nagari. }\end{array}$ \\
\hline 2 & $\begin{array}{l}1983- \\
2008 .\end{array}$ & $\begin{array}{l}\text { - } \\
\text { - } \\
\text { - } \quad \text { The singer appeared within the circle of galombang performers. } \\
\text { Women also performed galombang } \\
\text { - } \quad \text { Female performers wore traditional Minangkabau costumes } \\
\text { - } \quad \text { Group flags were still in use }\end{array}$ \\
\hline 3 & $\begin{array}{l}2008- \\
2018\end{array}$ & $\begin{array}{l}\text { - The singer appeared outside the circle, sitting with the external musicians. } \\
\text { - } \\
\text { professional groups. } \\
\text { - } \quad \text { Women participated as galombang performers, dressing and acting like men. } \\
\text { - } \\
\text { movementoments and hip shake } \\
\text { - A women'a Randai "Sirabuang Ameh" (as a model) emerged, reflecting the nature, } \\
\text { characteristics, and cultural ethics of Minangkabau women, while in the past it was deemed } \\
\text { inappropriate for women to appear as galombang performers of a Randai show. }\end{array}$ \\
\hline
\end{tabular}




\section{CLOSING}

Randai as a work of art lives and develops based on the creativity of its artists. An Artist creativity always leads to innovation and change. Without change and development, an art cannot survive. It will be extinct and abandoned by the life of people which is always developing and changing. Such preservation efforts are happening in Randai in Minangkabau. The activities of Randai artists are increasingly prevalent both in traditional communities and among professional artists and academics. As a result, there have been changes in various texts and contexts of Randai. These changes and developments directly affect the cultural ethics of Randai in Minangkabau.

\section{ACKNOWLEDGEMENTS}

This research was sponsored by Ministry of Research, Technology and Higher Education of the Republic of Indonesia (Kemenristekdikti RI). We thank our colleagues from ISI (Institute of Indonesian Arts) Padang Panjang who provided insight and expertise that greatly assisted this research.

\section{BIBLIOGRAPHY}

Bronislaw Malinoski. 1955. Sex and Repression in Savege Society. New Yord : Meridian Books. Dalam Muhammad Radjab. Sistem Kekerabatan di Minangkabau. Padang: Center For Minangkabau Studies Press, 1969.

Erlinda. 1999. "Kehadiran Wanita dalam Musik Malam (Saluang dan Dendang) Di Minangkabau Sumatera Barat". Laporan Penelitian. Akademi Seni Karawitan Indonesia (ASKI) Padangpanjang.

Erianjoni. 2011. Pergeseran Citra Wanita Minangkabau dari Konsepsi Ideal Tradisional ke Realitas. Kafa'ah: Jurnal Ilmiah Kajian Gender, 1(1), 225-43. $\quad$ Retrieved from. http://kafaah.org/index.php/afaaharticle/download/81/54

Hawkins M. Alma, 2003. Terjemahan . Sumandiyo Hadi. Mencipta Lewat Tari. Yogyakarta: Mantili

Indrayuda. 2013. Randai Suatu Aktivitas Kesenian dan Media Pendidikan Tradisional. Padang: PT. Grafika Sumbar bekerjaama dengan Dinas Kebudayaandan Pariwisata Provinsi Sumatera Barat. UPTD Taman Budaya.

Iva Ariani. 2012. "Nilai Filoofis Budaya Matrilineal Minangkabau (Relavansinya bagi Penegak Hak-Hak Perempuan Indonesia). Laporan Penelitian. Yogyakarta: FakultasFilsafat Universitas Gadjah Mada.

Mursal Esten. 1992. Tradisi dan Modernitas dalam Sandiwara. Jakarta: Intermasa.

Sahrul N. 2012. "Mamaknai Nilai Budaya Melayu Lewat Estetika Membumi” dalam Proceeding International Seminar Of Southeast Asia Malay Arts Festival. "Redicoveringthe Treasures ofMalayCulture". ISI Padangpanjang Press.

Suryanti. 2014. "Transformasi Randai dari Hiburan Menjadi Presentasi Estetis". Dalam Prosiding Seminar Nasional. Identitas Tubuh yang Mengglobal. Yogyakarta: Gre Publishing kerjasama Jurusan Tari Institut Seni Indonesia Padangpanjang.

Soedarsono. 2003. Seni Pertunjukan dari Perspektif Politik Sosial, dan Ekonomi. Yogyakarta: Gadjah Mada Universit Press.

Rusli Amran. 1986. Padang Riwayatmu Dulu. Jakarta: Mutiara Sumber Widia.

Zulkifli. 1993. "Randai Sebagai Teater Rakyat Minangkabau di Sumatera Barat Dalam Dimensi Sosial Budaya". Tesis. Pasca Sarjana S2. Universitas Gadjah Mada Yogyakarta.

2016. "Konsep Kesenian Randai sebagai Teater Tradisional Minangkabau”. Kertas Kerja untuk Workshop Randai. Payakumbuh 7- 9 Maret 2016. 